\title{
Pengaruh Frekuensi Pemberian Pakan dan Periode Pemberian Pakan terhadap Kecernaan Ayam Buras Super
}

\section{Effect of Feeding Frequence and Feeding Periods on Crossbred Native Chicken Digestibility}

\author{
A. W. Trisnanto, E. Suprijatna, dan B. Sukamto \\ Faculty of Animal Husbandry and Agriculture, University of Diponegoro, Semarang \\ Kompleks Drh. R. Soejono Koesoemowardjo, Tembalang Semarang \\ Email: andrewwijitrisnanto@gmail.com
}

\begin{abstract}
This study was aimed to evaluate the effect of feeding frequency and feeding period to get the efficient feeding treatment. The material used in this study were 252 DOC crosbreds native chicken with initial weight $37.88 \pm 1.98 \mathrm{~g}$ (CV : 5.02\%). Commercial feed used in this study consists of $21 \% \mathrm{CP}$ and $2900 \mathrm{kkal} / \mathrm{kg}$ EM for starter and $19 \% \mathrm{CP}$ and $2900 \mathrm{kkal} / \mathrm{kg}$ EM for finisher. This study used Split Plot experimental design with 3 levels feeding frequency F1 (once), F2 (Twice) and F3 (thrice) as main plot and 3 levels feeding period P1 (14 hours), P2 (16 hours) and P3 (18 hours) as sub plot in 4 replications that were arranged in 36 experimental units, each unit consists of 7 chickens. The collect data were analyzed using F test at 5\% level and for the significantly different result used duncan test. The results showed that the interaction between feeding frequency and feeding period was significantly different $(p<0.05)$ on CP and EE digestibility, as well as significantly affected from single factor of each feeding frequence and feeding periods $(\mathrm{p}<0.05)$ on $\mathrm{CF}$ digestibility.
\end{abstract}

Key words : crossbreds native chicken, performance, feeding, frequency, time period

\begin{abstract}
ABSTRAK
Tujuan dari penelitian ini adalah untuk mengevaluasi pengaruh manajemen pemberian pakan terhadap kecernaan pakan untuk mendapatkan efisiensi penggunaan pakan yang terbaik. Materi yang digunakan pada penelitian ini meliputi 252 ekor anak ayam buras super umur 1 hari (DOC). Rata-rata bobot badan DOC 37,88 $\pm 1,98 \mathrm{~g}(\mathrm{CV}$ : $5,02 \%$ ). Pakan yang digunakan adalah pakan komersial, periode starter dengan PK 21\% dan EM $2.900 \mathrm{kkal} / \mathrm{kg}$, periode finisher dengan PK 19\% dan EM $2.900 \mathrm{kkal} / \mathrm{kg}$. Penelitian ini menggunakan rancangan split plot design dengan main plot yaitu 3 taraf frekuensi pemberian pakan yang terdiri dari F1 (1x/hari), F2 (2x/hari), F3 (3x/hari) dan sub plot yaitu 3 taraf periode pemberian pakan yang terdiri dari P1 (14 jam), P2 (16 jam), P3 (18 jam) dengan 4 ulangan sehingga menggunakan 36 unit percobaan, masing-masing unit percobaan berisi 7 ekor. Data yang diperoleh dianalisis menggunakan analisis ragam dan uji $\mathrm{F}$ pada taraf $5 \%$, kemudian dilanjutkan uji Duncan untuk data yang berbeda nyata. Hasil penelitian menunjukkan bahwa terdapat pengaruh interaksi frekuensi dan periode pemberian pakan $(\mathrm{P}<0,5)$ terhadap nilai kecernaan $\mathrm{PK}$ dan $\mathrm{LK}$, serta faktor frekuensi dan periode berpengaruh nyata $(\mathrm{P}<0,5)$ terhadap nilai kecernaan SK.
\end{abstract}

Kata kunci : ayam buras super, performa, pemberian pakan, frekuensi, awal

\section{PENDAHULUAN}

Ayam buras super merupakan persilangan antara ayam kampung dengan ayam ras. Kebutuhan ayam kampung di Indonesia semakin tinggi namun ketersediaannya tidak dapat memenuhi permintaan yang ada. Hal ini terlihat dari peningkatan produksi ayam kampung dari tahun ke tahun, dimana pada tahun 2001-2005 terjadi peningkatan sebanyak $4,5 \%$ dan pada tahun 2005-2009 konsumsi ayam kampung dari 1,49 juta ton meningkat menjadi 1,52 juta ton (Aman, 2011). Berdasarkan hasil survey Badan Pusat Statistik (BPS) menunjukkan bahwa pada periode 2007 - 2014 jumlah konsumsi ayam kampung rata-rata per kapita mengalami peningkatan. Kebutuhan pasar tersebut belum dapat dipenuhi oleh peternakan 
ayam buras di Indonesia karena pemeliharaannya dalam skala usaha kecil, kondisi lingkungan yang terbatas, produktivitas yang masih rendah, pertumbuhan yang lambat, serta sifat alami (mengeram dan mengasuh) yang belum hilang (Muryanto et al., 2005; Suryana et al., 2008; Romanov, 2001).

Pakan merupakan bagian dari faktor lingkungan yang perlu mendapat perhatian khusus, mengingat biaya pakan dalam usaha peternakan menduduki biaya tertinggi yaitu kurang lebih 65\% dari biaya produksi (Nort dan Bell, 1990). Salah satu manajemen pemberian pakan yang dapat diterapkan adalah pemberian pakan pada pagi hari, karena berkaitan dengan suhu lingkungan Indonesia yang berfluktuasi. Dilihat dari perubahannya dari suhu rendah, tinggi, kemudian turun lagi maka dapat diperkirakan suhu nyaman pada ayam yaitu pada pagi hari. Suhu udara di daerah tropis akan mencapai titik terendah pada jam $05.00-06.00$ pagi sebesar $19^{\circ} \mathrm{C}$ dan terus naik hingga mencapi puncak pada jam 12.00-13.00 sebesar $32,2^{0} \mathrm{C}$ (Hafni et al., 2015).

Periode pemberian pakan pada pagi hari harus dipertimbangkan untuk waktu awal pemberian pakan sehingga saat ternak berada pada puncak metabolismenya terhindar dari cekaman panas akibat suhu udara yang juga tinggi karena metabolisme pada ternak juga akan menghasilkan panas tubuh. Jika hal ini terjadi maka pakan yang dikonsumsi tidak digunakan untuk memproduksi energi dalam tubuh melainkan akan digunakan untuk mempertahankan suhu tubuh sehingga pakan menjadi tidak efisien. Selain itu, saat suhu lingkungan tinggi maka ternak juga akan mengurangi konsumsi pakannya untuk menghindari cekaman panas. Oleh sebab itu waktu nyaman ternak harus diketahui dan pemberian pakan dapat di maksimalkan pada kondisi tersebut. Waktu pemberian ransum selama 8 jam setiap hari dapat meningkatkan bobot badan akhir dan konversi ransum lebih rendah (Yule dan Fueling, 1979 dalam Zulfanita et al., 2011). Menurut Nastiti (2010), jatah pemberian ransum dalam satu hari tidak boleh diberikan terlalu banyak, namun harus diatur agar bisa diberikan lebih dari 2 kali sehari dikarenakan dapat menghemat ransum, mengurangi resiko kandang kotor karena tumpahan ransum, menambah nafsu makan dan ayam tidak malas untuk minum. Beberapa penulis menemukan kecernaan nutrisi yang lebih baik ketika ada pembatasan konsumsi pakan (Teeter et al., 1985 dan Yalda et al., 1996). Secara umum bahwa setelah dilakukan pembatasan pemberian pakan, pertumbuhan pada ternak akan tercapai (Summers et al., 1990; Lee dan Leeson, 2000). Menurut Tumova et al., (2003) manfaat ekonomi dari pembatasan pakan yaitu dapat meningkatkan efisiensi pakan yang diberikan pada trernak.

Frekuensi pemberian pakan akan berkaitan dengan kesempatan ternak untuk mengakses pakan. Untuk mendapatkan pertambahan bobot badan yang maksimal maka sangat perlu diperhatikan keadaan kuantitas pakan (Yamin, 2002). Lama waktu untuk mengakses pakan tentu akan mempengaruhi laju pakan di dalam saluran pencernaan yang akan menentukan jumlah nutrien pakan yang mampu diserap oleh usus atau kecernaan nutrien pakan. Laju pakan yang melambat didalam saluran pencernaan akan membuat kerja organ pencernaan lebih efektif karena dapat lebih lama menghidrolisis pakan. 
Hal ini tentu saja akan berpengaruh pada kecernaan serta performans ayam karena untuk dapat berproduksi optimal maka kebutuhan nutrien harus terpenuhi. Dengan adanya pengurangan kecernaan pakan maka dapat menurunkan jumlah nutrisi yang tersedia untuk pertumbuhan (Bonnet et al., 1997). Kecernaan nutrien pakan yang baik akan memberikan efisiensi penggunaan pakan yang tentu saja bersifat menguntungkan bagi peternak. Ollong et al. (2012) menyatakan bahwa perbaikan kecernaan pakan yang digunakan mampu menghasilkan pertambahan bobot badan (PBB) yang lebih tinggi.

\section{MATERI DAN METODE}

Penelitian menggunakan materi 252 ekor DOC ayam buras super umur 1 hari. Rata-rata bobot badan DOC 37,88 $\pm 1,98 \mathrm{~g}$ (CV : 5,02\%). Pakan yang digunakan adalah pakan komersial, periode starter B11S dengan PK 21\% dan EM $2.900 \mathrm{kkal} / \mathrm{kg}$, periode finisher B12S dengan PK 19\% dan EM 2.900 kkal $/ \mathrm{kg}$. Penelitian ini menggunakan rancangan dasar RAL model split plot design dengan main plot yaitu 3 taraf frekuensi pemberian pakan dan sub plot yaitu 3 taraf periode pemberian pakan dengan 4 ulangan sehingga menggunakan 36 unit percobaan masing-masing unit percobaan berisi 7 ekor.

Tabel 1. Perlakuan kombinasi frekuensi pemberian pakan dan periode pemberian pakan

\begin{tabular}{clll}
\hline \multirow{2}{*}{ Perlakuan } & \multicolumn{2}{c}{ P1 } & \multicolumn{1}{c}{ P2 } \\
\cline { 2 - 4 } & \multicolumn{1}{c}{ Jam pemberian pakan dan porsi pemberian pakan } \\
\hline F1 & $08.00(100 \%)$ & $06.00(100 \%)$ & $04.00(100 \%)$ \\
F2 & $08.00(50 \%)$ dan 17.00 & $06.00(50 \%)$ dan 17.00 & $04.00(50 \%)$ dan 17.00 \\
& $(50 \%)$ & $(50 \%)$ & $(40 \%)$ \\
F3 & $08.00(40 \%), 14.00(10 \%)$, & $06.00(40 \%), 14.00$ & $04.00(40 \%), 14.00$ \\
& dan $17.00(50 \%)$ & $(10 \%)$, dan $17.00(50 \%)$ & $(10 \%)$, dan $17.00(50 \%)$ \\
\hline
\end{tabular}

Keterangan : P1 (periode 14 jam) ; P2 (periode 16 jam) ; P3 (periode 18 jam) ; F1 (frekuensi 1 kali) ; F2 (frekuensi 2 kali) ; F3 (frekuensi 3 kali)

Tabel 2. Kandungan nutrien pakan dalam kering udara

\begin{tabular}{lcc}
\hline \multirow{2}{*}{ Nutrien } & \multicolumn{2}{c}{ Jenis pakan } \\
\cline { 2 - 3 } & Starter & Finisher \\
\hline Kadar Air (\%) & 12,22 & 11,97 \\
PK $(\%)$ & 21,02 & 20,44 \\
LK $(\%)$ & 6,71 & 4,03 \\
SK $(\%)$ & 3,27 & 4,56 \\
Ca (\%) & 1,00 & 0,82 \\
P (\%) & 0,44 & 0,33 \\
EM (Kkal) & $2759,89 *$ & $2601,42 *$ \\
\hline
\end{tabular}

Keterangan : * $\mathrm{EM}=40,81(0,87(\mathrm{PK}+(2,25 \mathrm{x}$ LK $)+\mathrm{BETN})+2,5)$

(Carpenter dan Clegg, 1956 dalam Aggorodi, 1985)

Ayam dipelihara di kandang lantai liter dengan ukuran 120 x 50 x $40 \mathrm{~cm}$, setiap unit berisi 7 ekor ayam. Ayam dipelihara mulai dari umur 0 sampai 12 minggu. Pengambilan data dilakukan pada fase finisher yaitu pada umur 12 minggu. Jadi untuk mengamati kecernaan diambil 2 sampel menggunakan metode total koleksi. Kandang disekat menjadi 
2 bagian untuk menempatkan ayam yang akan diambil datanya. Total koleksi dilakukan selam 3 hari, pada hari pertama dilakukan pemuasaan selama satu hari untuk memastikan saluran pencernaan ternak kosong, hari ke dua ternak diberi pakan sesuai dengan perlakuan kemudian dilakukan penampungan ekskreta sampai hari ketiga, hari ke tiga ternak kembali dipuasakan untuk memastikan ekskreta yang berasal dari pakan yang diberikan pada hari kedua tertampung. Sampel feses kemudian dikeringkan, dihaluskan, dan dianalisis kadar air, bahan kering, kadar abu, protein kasar, lemak kasar, dan serat kasar. Data yang diperoleh dianalisis menggunakan analisis ragam dan uji $\mathrm{F}$ pada taraf $5 \%$, kemudian dilanjutkan uji Duncan untuk data yang berbeda nyata.

Parameter yang diukur meliputi :

Kecernaan protein kasar dihitung dengan rumus (Wahju, 1997) sebagai berikut:

Kecernaan PK $(\%)=\frac{\text { Konsumsi Protein }-\mathrm{PK} \text { ekskreta terkoreksi }}{\text { Konsumsi Protein }} \times 100 \%$

Keterangan :

PK yang dikonsumsi = kadar protein kasar ransum $\mathrm{x}$ jumlah konsumsi

Protein ekskreta = jumlah ekskreta $\mathrm{x}$ PK ekskreta

Protein urin $\quad=30 \%$ x protein ekskreta (Muller, 1982)

PK ekskreta terkoreksi $\quad=$ PK ekskreta - PK urine

Rumus perhitungan serat kasar (Tilman et al.,1991) sebagai berikut :

Kecernaan SK $(\%)=\frac{\text { Konsumsi serat kasar-Serat kasar ekskreta }}{\text { Konsumsi serat kasar }} \times 100 \%$

Keterangan :

Konsumsi serat kasar = kadar serat kasar ransum $\mathrm{x}$ jumlah konsumsi

Serat kasar ekskreta = jumlah ekskreta $\mathrm{x}$ SK ekskreta

Kecernaan lemak kasar dihitung dengan menggunakan indikator yang digunakan Coen, et al. (1996) sebagai berikut :

Kecernaan LK(\%) $=\frac{\text { Lemak kasar pakan-lemak kasar ekskreta }}{\text { Kandungan lemak kasar dalam pakan }} \times 100 \%$

Keterangan :

Lemak kasar ekskreta = jumlah ekskreta $\mathrm{x}$ LK ekskreta.

\section{HASIL DAN PEMBAHASAN}

\section{Konsumsi Ransum}

Konsumsi ransum ayam buras super yang diberi perlakuan frekuensi dan periode pemberian pakan yang berbeda hasilnya seperti yang tercantum pada Tabel 3 . Berdasarkan Tabel 3 menunjukkan bahwa hasil penelitian rata-rata konsumsi ransum ayam buras super adalah 3.553,50 - 3.913,17 g/ekor. Hal ini menunjukkan bahwa konsumsi ransum ayam buras super tidak berbeda dengan penelitian Astuti (2012) yang menyatakan bahwa rata-rata konsumsi ransum ayam buras super yang diberi pakan konsentrat 
broiler (BR1) dengan pemeliharaan 12 minggu sebesar 3.723,48 g/ekor. Konsumsi ransum dipengaruhi oleh suhu lingkungan, ketika ayam berada di zona nyaman maka akan berdampak pada besarnya konsumsi ransum karena tidak adanya peningkatan suhu tubuh yang menyebabkan peningkatan konsumsi minum maupun terjadinya panting. Menurut Diarra dan Tabuaciri (2014) manajemen konsumsi ransum dipengaruhi oleh suhu lingkungan, pada daerah tropis kisaran suhu lingkungan dimana unggas mampu menjaga suhu tetap konstan berkisar antara $16-26^{\circ} \mathrm{C}$.

Tabel 3. Rata-rata konsumsi ransum ayam buras super (g/ekor/12 minggu)

\begin{tabular}{ccccc}
\hline & P1 & P2 & P3 & Rata-rata \\
\hline F1 & 3855,88 & 3913,17 & 3824,5 & 3864,52 \\
F2 & 3736,49 & 3858,7 & 3619,35 & 3738,18 \\
F3 & 3780,25 & 3553,5 & 3562,53 & 3632,09 \\
\hline Rata-rata & 3790,87 & 3775,12 & 3668,79 & \\
\hline
\end{tabular}

Kecernaan Protein Kasar pada Ayam Buras Super

Rataan kecernaan protein ayam buras super yang diberi perlakuan frekuensi pemberian pakan dan periode pemberian pakan, setelah dianalisis statistik dengan sidik ragam hasilnya seperti tercantum pada Tabel 4.

Tabel 4. Rata-rata kecernaan protein ayam buras Super

\begin{tabular}{|c|c|c|c|c|}
\hline & P1 & $\mathrm{P} 2$ & P3 & Rata-rata \\
\hline F1 & $86,33^{a b}$ & $\begin{array}{r}a b \\
88,83^{x y}\end{array}$ & $85,20^{b}$ & 86,78 \\
\hline $\mathrm{F} 2$ & $86,60^{y}$ & $89,79^{a}$ & $85,67^{b}$ & 87,35 \\
\hline F3 & $87,62^{a b}$ & $\begin{array}{r}b \\
86,20^{y}\end{array}$ & $89,45^{a}$ & 87,76 \\
\hline Rata-rata & 86,85 & 88,27 & 86,77 & \\
\hline
\end{tabular}

Berdasarkan tabel diatas dapat $80 \%$. Hal ini menunjukkan bahwa kecernaan diketahui bahwa kecernaan protein ayam buras protein masih dalam kisaran normal, karena super dengan perlakuan frekuensi pemberian temperatur rata-rata harian sebesar $28^{0} \mathrm{C}$ pakan dan periode pemberian pakan berkisar $85,20 \%$ - 89,79\%. Hal ini tidak jauh berbeda dari hasil penelitian Anggarayono et al. (2008) yang menyatakan bahwa dengan pemberian ransum 1 kali (F1) di siang hari menghasilkan kecernaan protein tertinggi yaitu 81,64\%. Menurut Wahju (1997) menyatakan bahwa kecernaan protein unggas berkisar antara 70sehingga ayam dalam kondisi termoneutral zone. Menurut Dahlan dan Hadi (2011) suhu yang baik untuk pertumbuhan ayam di daerah tropis adalah $14,7-28^{\circ} \mathrm{C}$.

Kecernaan protein kasar setelah dianalisis statistik menunjukkan pengaruh interaksi yang nyata $(\mathrm{P}<0,05)$ terhadap 
kecernaan protein kasar. Pola interaksinya bisa dilihat pada Gambar 1 dan Gambar 2.

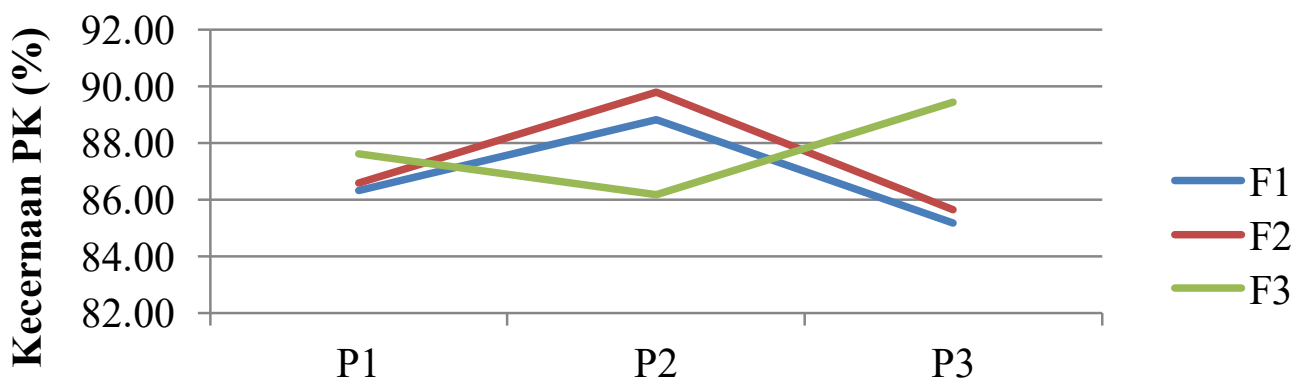

Gambar 1. Grafik pengaruh interaksi kecernaan protein kasar dari faktor frekuensi

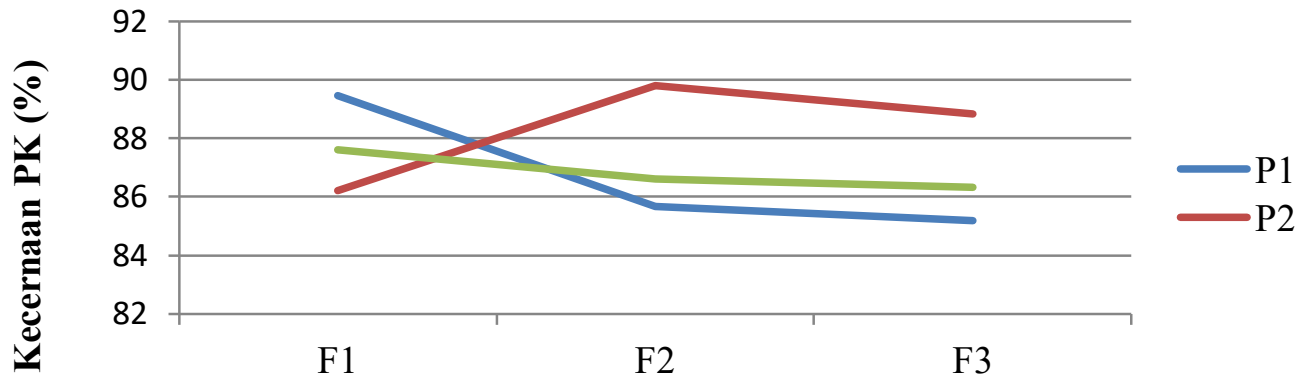

Gambar 2. Grafik pengaruh interaksi kecernaan protein kasar dari faktor periode

Seperti yang digambarkan pada menyebabkan meningkatkan kecernaan karena Gambar 1, dilihat dari faktor frekuensi ayam dapat makan setiap saat pada kondisi perlakuan pemberian pakan 1 kali (F1) dan 2 termoneutral sehingga dapat mengatur suhu kali (F2) meningkatnya periode tubuhnya dengan baik, sementara frekuensi 3 mengakibatkan meningkatnya kecernaan, kali (F3) tidak berbeda. Pada frekuensi 3 kali namun pada periode selanjutnya kecernaan (F3) kecernaannya menurun karena ayam yang menurun, sedangkan pada frekuensi 3 kali (F3) diberi pakan dengan waktu yang pendek maka meningkatnya periode mengakibatkan menurunnya kecernaan dan pada periode selanjutnya kecernaan tetap menurun.

Seperti yang digambarkan pada akan efisien, butuh pakan selalu ada, tetapi jika waktunya diperpanjang butuh pakan tidak ada sehingga tidak efisien. Kecernaan tergantung pada konsumsi ransum, jika waktu Gambar 2, dilihat dari faktor periode periode perlakuan periode 16 jam (P2) meningkatnya frekuensi pemberian pakan mengakibatkan meningkatnya kecernaan, namun pada frekuensi selanjutnya kecernaan menurun. Pada periode 14 jam (P1) dan 18 jam (P3) meningkatnya frekuensi pemberian pakan mengakibatkan kecernaan menurun, pada frekuensi selanjutnya kecernaan tetap menurun. makannya lama maka ketika diberi pakan konsumsinya akan cepat sehingga laju digesta juga cepat, tetapi jika waktu makannya diperpendek maka konsumsinya akan pelan sehingga bisa lebih efisien. Hal ini sesuai dengan pendapat Tillman et al. (1998) yang menyatakan bahwa tinggi rendahnya kecernaan protein dipengaruhi oleh kandungan protein bahan ransum dan banyaknya protein Pada ilustrasi 1 frekuensi 1 kali (F1) yang masuk dalam saluran pencernaan. dan 2 kali (F2) meningkatnya periode 
Kecernaan Serat Kasar pada Ayam Buras Super

Rataan kecernaan serat kasar ayam buras super yang diberi perlakuan frekuensi pemberian pakan dan periode pemberian pakan, setelah dianalisis statistik dengan sidik ragam hasilnya seperti tercantum pada Tabel 5 .

Tabel 5. Rata-rata kecernaan serat kasar ayam buras Super

\begin{tabular}{|c|c|c|c|c|}
\hline & $\mathrm{P} 1$ & $\mathrm{P} 2$ & P3 & Rata-rata \\
\hline $\mathrm{F} 1$ & 36,95 & 43,29 & 36,50 & $38,91^{b}$ \\
\hline F2 & 36,89 & 46,585 & 38,09 & $\begin{array}{r}a b \\
40,52^{x y}\end{array}$ \\
\hline F3 & 43,57 & 42,29 & 44,36 & $43,41^{a}$ \\
\hline Rata-rata & 39,14 & 44,06 & 39,65 & \\
\hline
\end{tabular}

Berdasarkan tabel di atas dapat diketahui bahwa rata-rata kecernaan serat kasar adalah 40,59. Hasil tersebut lebih tinggi berdasarkan penelitan Wulandari et al. (2013) bahwa kecernaan serat kasar pada ayam dengan kandungan serat kasar ransum 16,87\% adalah $23,34 \%$. Kecernaan serat kasar yang lebih tinggi disebabkan oleh ransum yang digunakan pada penelitian ini memiliki kandungan serat kasar yang lebih rendah. Kandungan serat kasar pada ransum sangat mempengaruhi pada kecernaan serat kasar. Tillman et al. (2005) menyatakan bahwa kecernaan serat kasar tergantung pada kandungan serat kasar dalam ransum dan jumlah serat kasar yang dikonsumsi, sehingga kecernaan serat kasar dalam penelitian ini masih tergolong normal. Berdasarkan frekuensi pemberian pakan ayam buras super kecernaan paling tinggi adalah pada frekuensi 3 kali (F3) karena pemberian pakan semakin sering menyebabkan laju digesta yang lambat sehingga kecernaan serat kasar tinggi.

Hasil analisis ragam kecernaan serat kasar dengan perlakuan frekuensi pemberian pakan dan periode pemberian pakan berpengaruh nyata $(\mathrm{p}<0,05) \quad$ terhadap kecernaan serat kasar ayam buras super.

Kecernaan serat kasar paling tinggi adalah frekuensi pemberian pakan 2 kali periode 16 jam (F2P2), sedangkan kecernaan serat kasar paling rendah adalah frekuensi pemberian pakan 1 kali 14 jam (F1P1). Pada waktu ini merupakan jangka 2 jam sebelum suhu lingkungan mulai naik, sedangkan pada jam ini suhu lebih tinggi daripada pemberian pakan jam 04.00 dan 06.00 WIB. Suhu lingkungan dalam kandang pada jam 08.00 yaitu $27,1^{\circ} \mathrm{C}$ dan di luar kandang yaitu $28,09^{\circ} \mathrm{C}$, meskipun frekuensi pemberian pakan 1 kali (F1) tetapi dengan periode penyajian ransum yang singkat menjadikan kesempatan ayam mengkonsumsi ransum menjadi lebih pendek sehingga pakan banyak disimpan di tembolok untuk mnghindari penambahan beban panas tubuh saat suhu lingkungan meningkat di siang hari. Pakan akan dicerna kembali saat kondisi lingkungan kembali ke zona nyaman ayam. Hal tersebut mengakibatkan beban untuk mencerna serat kasar menjadi tidak berat sehingga kecernaan serat kasar cenderung lebih kecil dari 
perlakuan yang lain. Aktivitas enzim pencernaan akan menurun selama cekaman panas (Osma dan Tanios, 1982).

Pada penelitian ini pakan yang digunakan adalah ransum komersial dimana kandungan serat kasar pada setiap perlakuan sama, sehingga kecernaan serat kasar pada setiap perlakuan perbedaannya tidak terlalu signifikan. Kecernaan serat kasar pada setiap perlakuan yaitu antara 36,50\% - 46,58\%, sedangkan kecernaan serat kasar dipengaruhi oleh kandungan serat kasar dalam ransum dan jumlah pakan yang di konsumsi. Hal ini sesuai dengan pendapat Maynard et al., (2005) yang menyatakan bahwadaya cerna serat kasar dipengaruhi oleh beberapa faktor antara lain kadar serat dalam pakan, komposisi penyusun serat kasar dan aktifitas mikroorganisme.

\section{Kecernaan Lemak Kasar pada Ayam Buras Super}

Rataan kecernaan lemak kasar ayam buras super yang diberi perlakuan frekuensi pemberian pakan dan periode pemberian pakan, setelah dianalisis statistik dengan sidik ragam hasilnya seperti tercantum pada Tabel 6 .

Tabel 6. Rata-rata kecernaan lemak ayam buras Super

\begin{tabular}{|c|c|c|c|c|}
\hline & $\mathrm{P} 1$ & $\mathrm{P} 2$ & P3 & Rata-rata \\
\hline F1 & $68,56^{b}$ & $77,49 x^{a}$ & $\begin{array}{r}b \\
66,17^{y}\end{array}$ & 70,74 \\
\hline $\mathrm{F} 2$ & $70,49{ }^{a}$ & $75,88^{a}$ & $69,87^{a}$ & 72,08 \\
\hline F3 & $78,30{ }^{a} x$ & $73,49 x^{a}$ & $73,39 x^{a}$ & 75,06 \\
\hline Rata-rata & 72,45 & 75,62 & 69,81 & \\
\hline
\end{tabular}

Berdasarkan Tabel 6 dapat diketahui bahwa kecernaan lemak ayam buras super dengan perlakuan frekuensi pemberian pakan dan awal pemberian pakan berkisar $66,17 \%$ $78,30 \%$. Hal ini tidak jauh berbeda dari hasil penelitian Sukaryana et al. (2011) yang menyatakan bahwa ransum dengan campuran bungkil sawit dan dedak padi rata-rata adalah $66,33 \%-87,14 \%$. Frekuensi pemberian pakan
1 kali 14 jam (F1P1) menunjukkan kecernaan paling rendah, sedangkan kecernaan paling tinggi adalah frekuensi pemberian pakan 3 kali 18 jam (F3P3).

Kecernaan lemak kasar setelah dianalisis statistik menunjukkan pengaruh interaksi nyata $(\mathrm{P}<0,05)$ terhadap kecernaan lemak kasar. Pola interaksinya bisa dilihat pada Gambar 3 dan Gambar 4.

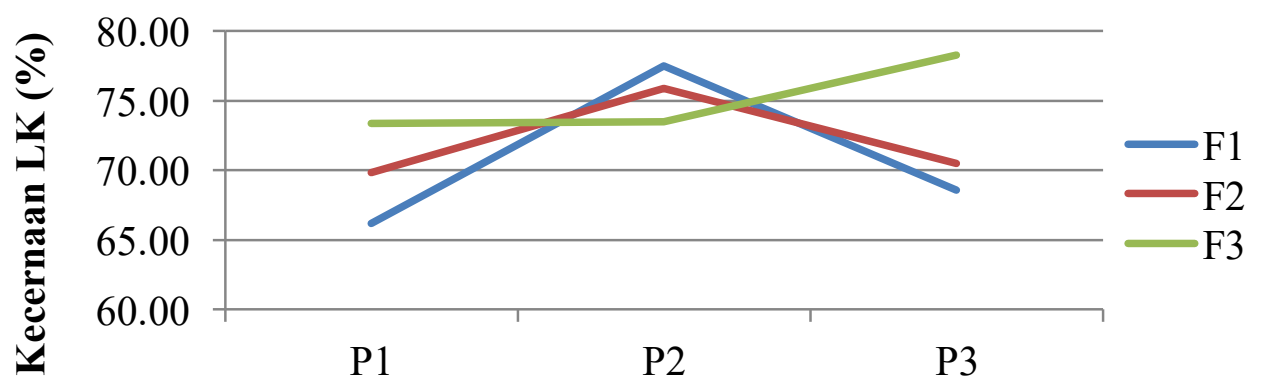

Gambar 3. Grafik pengaruh interaksi kecernaan lemak kasar dari faktor frekuensi 


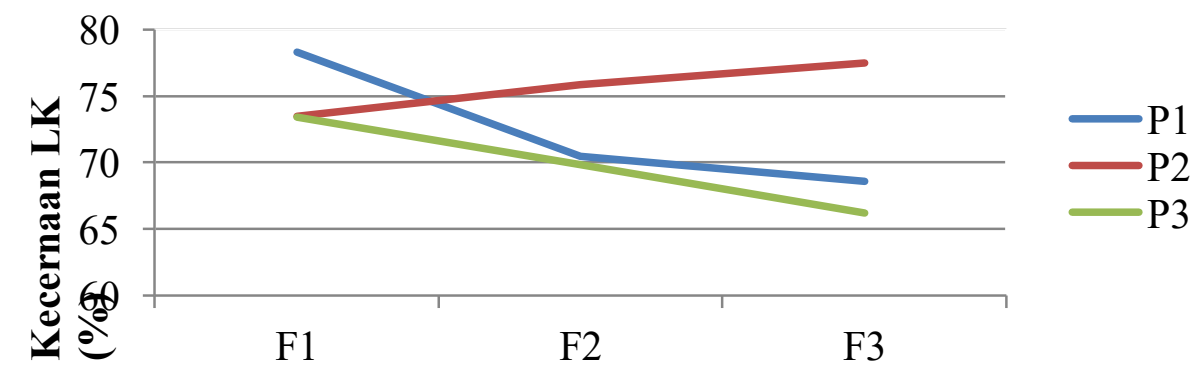

Gambar 4. Grafik pengaruh interaksi kecernaan lemak kasar dari faktor periode

Seperti yang digambarkan pada Gambar 3, dilihat dari faktor frekuensi perlakuan pemberian pakan 1 kali (F1) dan 2 kali (F2) meningkatnya periode mengakibatkan meningkatnya kecernaan, namun pada periode selanjutnya kecernaan menurun, sedangkan pada frekuensi 3 kali (F3) meningkatnya periode mengakibatkan meningkatnya kecernaan dan pada periode selanjutnya kecernaan semakin tinggi

Seperti yang digambarkan pada Gambar 4, dilihat dari faktor periode perlakuan pemberian pakan periode 16 jam (P2) meningkatnya frekuensi mengakibatkan meningkatnya kecernaan, pada frekuensi selanjutnya kecernaan semakin meningkat, sedangkan pada periode 14 jam (P1) dan 18 jam (P3) meningkatnya frekuensi mengakibatkan menurunnya kecernaan dan pada frekuensi selanjutnya kecernaan semakin menurun

Pada Tabel 6 kecernaan lemak kasar paling rendah adalah frekuensi pemberian pakan 1 kali 14 jam (F1P1). Berdasarkan kecernaan lemak kasar menjadi rendah karena meskipun frekuensi pemberian pakan satu kali (F1) yang berarti pakan selalu tersedia tapi periode penyajian yang singkat mengakibatkan pakan dicerna secara bertahap. Pakan terlebih dahulu disimpan dalam tembolok untuk menghindari kenaikan suhu lingkungan. Saat keadaan kandang sudah termasuk comfort zone, sehingga mengurangi beban dalam mencerna lemak kasar. Telah ditunjukkan bahwa kenaikan suhu dan stres panas dapat mengurangi kecernaan bahan kering, protein, dan karbohidrat, sedangkan lemak kecernaan relatif tidak terpengaruh (Puvadolpirod dan Thaxton, 2000).

\section{KESIMPULAN}

Hasil penelitian menunjukkan adanya interaksi pada frekuensi dan periode pemberian pakan terhadap kecernaan protein kasar dan lemak kasar, tetapi tidak pada serat kasar. Frekuensi 2 kali 16 jam tertinggi pada kecernaan protein kasar dan serat kasar, sedangkan frekuensi 3 kali 18 jam tertinggi pada kecernaan lemak kasar.

\section{DAFTAR PUSTAKA}

Aman, Y. 2011. Ayam Kampung Unggul. Penerbit Penebar Swadaya. Jakarta.

Astuti, N. 2012. Kinerja ayam kampung dengan ransum berbasis konsentrat broiler. Jurnal Agribisnis. Yogyakarta. 4 (5): $51-58$.

Bonnet, S., P. A. Geraert, M. Lessire, B. Carre, and S. Guillaumin. 1997. Effec of high ambient temperature on feed digestibility in broilers. Institut National de la Recherche Agronomique, 37380 Nouzilly. France. 2 : 857-863. 
Coen, H. M., S. Chantal., A. A. Maarsen, M. V. Johan, M. Mouwen and F. J. G. Koninkx. 1996. The antinutritive effect of a carbocymethylcellulose with high viscosity in broiler chickens is not assosiated with mucosal damage. In: Viscosity of dietary fibre in relation to lipid digestibility in broiler chickens, Proefchrift. pp. 71-79.

Dahlan, M. dan N. Hudi. 2011. Studi Manajemen Ayam Broiler di Dusun Wangket Desa Kaliwates Kecamatan Kembangbahu Kabupaten Lamongan. Jurnal Ternak. Program Studi Peternakan Fakultas Peternakan Universitas Islam Lamongan. 2 (1) : 24 -29 .

Hafni, W., D. Pujiastuti, dan W. Harjupa. 2015. Analisis variabilitas temperatur udara di daerah Kototabang periode 2003 2012. J. Fisika Unand. 4 (2) : 185-192.

Leeson, S. and J. D. Summers. 2001. Scott's nutrition of the chicken, 4th ed., Guelph, University Books, Canada.

Maynard, L.A., J. K. Loosil, H. F. Hintz, and R. G. Warner. 2005. Animal Nutrition. (7th Edition) McGraw-Hill Book Company. New York, USA..

Muryanto, P. S. Hardjosworo, R. Herman, dan H. Setijanto. 2002. Evaluasi Karkas Persilangan Antara Ayam Kampung Jantan dengan Ayam Ras Petelur Betina. Animal Production. 4 (2): 7176.

Nastiti, R. 2010. Menjadi Milyarder Budidaya Ayam Broiler. Pustaka Baru Press. Yogyakarta.

North, M. O. and D. D. Bell. 1990. Commercial Chicken Production Manual. Fourth ed. An AVI Book. Van Nostrand Riinhold, New York.
Ollong, A. R., Wihandoyo dan Erwanto. 2012. Penampilan produksi ayam broiler yang diberi pakan mengandung minyak buah merah (Pandanus conoideus lam.) pada aras yang berbeda. Buletin Peternakan. 36 (1) : 14-18.

Osman, A. M. and N. I. Tanios. 1982. The Effect of heat on the intestinal and pancreatic levels of amylase and maltase of laying hens and broilers. J. Physio and Biochemi, University of Khartoum, Shambat. 75A. (4) : 563567.

Puvaldolpirod, S. and J. P. Thaxton. 2000. Model of physiological stress in chickens 4. Digestionand metabolism. Poultry Science 79: 383-390.

Romanov, M. N. 2001. Genetics of Broodiness in Poultry - A Review. Asian Australian Journal Animal Science. 14 (11): 1647- 1654.

Summers, J. D., D. Spratt. and J. L. Atkinson. 1990. Restricted feedand compensatory growth for broiler, Poult. Sci., 69 : 1855-1861.

Suryana, A. Hasbianto. 2008. Usaha Tani Ayam Buras di Indonesia: Permasalahan dan Tantangan. Jurnal Litbang Pertanian. 27 (3): 75-83.

Teeter R. G., M. O. Smith. 1985. Feed intake effects upon gain, carcass yield, and ration digestibility in broilers force fed five feed intakes. Poultry Science. 64: 2155-2160.

Tillman, A. D., H. Hartadi, S. Reksohadiprodjo, S. Prawirokusumo dan S. Lebdosoekojo. 1998. Ilmu Makanan Ternak Dasar. Gadjah Mada University Press, Yogyakarta.

Tillman, A. D., S. Reksohadiprodjo, S. Prawirokusumo dan S. Lebdosoekojo. 2005. Ilmu Makanan Ternak Dasar. 
Gadjah Mada University Press, Yalda, A. Y., Forbes, J. M. 1996. Effects of Yogyakarta.

Tilman, et.al. 1991. Ilmu Makanan TernakDasar. Gajah Mada University. Yogyakarta. food intake, soaking time, enzyme and cornflour addition on the digestibility of the diet and performance of broilers given wet food. British Poultry Science. 37:797-807.

Tumova, E., Skrivanova, V., and M. Skrivan. 2003. Effect of restricted feeding time and quantitativerestriction in growing rabbits. Archiv für Geflu"gelkunde.67 (4): 182-190

Wahju, J. 1997. Ilmu Nutrisi Unggas. UGM Press, Yogyakarta.

Wahju, J. 2004. Ilmu Nutrisi Unggas. Cetakan ke lima. Gadjah Mada UniversityPress, Yogyakarta

Yamin, M. 2002. Pengaruh Tingkat Protein Pakan terhadap Konsumsi, Pertambahan Bobot Badan dan IOFC Ayam Buras Umur 0-8 Minggu. Jurnal Agroland 9 (3). September 2002.

Zulfanita, et al. 2011. Pembatasan Ransum Berpengaruh terhadap Pertambahan Bobot Badan Ayam Broiler pada Periode Pertumbuhan. Jurnal Ilmu -ilmu Pertanian. 7. 